\title{
Code-Switching/Code Mixing in the National Assembly of Niger
}

\section{Aboubakar Nana Aichatou}

\author{
English Department, Université Abdou Moumouni, Niamey-Niger
}

nanaaichatou7@yahoo.com

\begin{abstract}
The Constitution of Niger Republic stipulates: "All the communities that compose the Nation of Niger have the liberty to use their languages while being considerate of others" (Article 3), but nothing as to the language (uniquely French or also any other native/national languages) in which the business of the national Assembly is to be conducted whereas the Assembly debates are public (Article 75) and intended toward a population of which only $22 \%$ is educated. This paper examines the level at which French, the official language or Hausa the major lingua franca and any other national language is used by the Niger Assembly members in carrying out debates.

Using some instruments such as questionnaire, tape recorded materials and observations the research reveals, in spite of the constitutional 'vide', the existence of code mixing/code-switching during debates by the Niger legislature. It also investigates the perception/attitude toward those MPs who switch codes, the reason why and the possible impact on the most notable absentees the population.
\end{abstract}

Keywords- National Assembly Language use Code-Switching, Code-Mixing, National languages, Non educated, Perception/Attitude.

\section{INTRODUCTION}

The constitution of the Republic of Niger (2010) stipulates, "All the communities that compose the Nation of Niger have liberty to use their languages while being considerate of others'."(Article 3), "French is the official language."(Titre1). Contrary to the constitution of the federal Republic of Nigeria (1979, 1989 and 1999) as quoted by Jimoh (1999), which clearly stipulates that: «the business of a House of Assembly shall be conducted in English, but this House may in addition to English conduct the business of the House in one or more other languages spoken in the state as the House may by resolution approve (section 91); should the business of the House be conducted in French or, might the House conduct its business in one or other languages spoken in the country? The Constitution only stipulates that "French is the official language". It is used in administration, education, justice, and other key institutions. But, each Member of Parliament represents the Nation (article 87) otherwise the population. What is noticed is that the business of the house is conducted mainly in French, whereas the population of Niger is at approximately $78 \%$ illiterate: the debates are public. Nevertheless, there are members of the House who switch/mix codes during the business debates, use other national languages together with French.

The present article tries to answer, amongst others the followings: how can the population be able to follow the business being transacted, on their behalf when debate is being held in French? How can the population know whether their elected members defend and protect their right, will and need let alone to voice their "feel"? Why does Code Switching occur? How those who code switch/mix are perceived by those who do not, the types of code switching; to answer the research questions, qualitative \& quantitative data were collected through questionnaire, observation and tape recorded materials.

\section{THE LEGISLATURE}

For Hornby (2006), the legislature refers to "a group of people who have the power to make and change laws." In Niger Republic, legislative power is carried out by a unique chamber named national Assembly whose members bear the title of deputies (article 83). The Legislature performs three basic functions, as follows: "They endeavour to manage the passage of bills or laws. They vote laws. They control the Government actions" (90). The sessions of the National Assembly are open (93).

\section{ETHNOGRAPHIC TRUST BUILDING: INTERLOCUTORS BETWEEN WARINESS AND COOPERATIVENESS}

It is not always easy to gain the speakers' trust. In spite of their status: representative of a population made of almost $72 \%$ illiterate there were MPs, especially those 
with high level of education whose reticence to be treated as objects of analysis was quite tangible and an impediment. They were the upper class informants and then, the more suspicious about the aims of my research following the example of this lecturer, which without wanting to find out, in details what my real intentions were, asked overtly his colleagues not to fill in the questionnaires. Such mistrust is typical of the bourgeoisie in Pierre Bourdieu's view point (in Review of cultural studies 94-95) that, in this case prevent me from reaching my universe in its whole.

Nevertheless, there were those who were more cooperative what permits me gather consistent data. Also, an emblematic example of reticence is contained in the following: the first time I called on the agent in charge of the Assembly audiovisual/sound archives he gave me about ten tape recordings promising to give me more once I brought it back. The second time I went to the Assembly the same agent told me: 'Mmmh, you're already back! Except the very person in charge did not turn up yet. I don't know her whereabouts'. This tangible and sharp irony in addition to that of the MPs was an indirect sign of non-cooperativeness and reticence to contribute, and moreover, it seemed to me an ethical reproach of my research aims.

\section{METHODOLOGY}

In order to gather the primary data, questionnaire, tape recording and observation were the research instruments used. As to the population, only a few attended tertiary institutions while most of them attended secondary institutions with $25 \%$ non-western educated.

The data on which this paper is based is obtained from a number of sources. Quite a number of text books, articles, and seminar papers have been read and exploited. However for the purpose of analysis only a limited number of 39 subjects were used. In all 113 questionnaires would have been distributed out of which only 39 were fully responded.

Two kinds of data are elicited for the analysis:

1. The first one related to the use of both Languages in order to prove the degree of code-switching in the Assembly;

2. Determine the perception/attitude of those who do not make use of code-switching during the debates while they are addressing a whole population made of $72 \%$ non western educated

In an attempt to elicit the data toward achieving our objective the questions were framed in such a way to enable the informants give on spontaneous answers so that the desired, adequate responses can then be drawn out.
Despite, we encountered difficulties.

It is well known that not all literates have the habit to write down their thoughts. In fact, even among the literates only certain group (those belonging to the higher social strata) appear willing to fill in questionnaires fully; what is not the case in this very context. The fact remains that some questionnaires were returned unfilled at all, or with one or 2 out of 3 questions unanswered: they have not been used in the analysis. This was the limitations of this our research.

\section{CODE SWITCHING/ CODE MIXING}

Linguists in general and sociolinguists in particular diverge on the distinction between Code Switching and Code Mixing.

Some scholars such as Wardhaugh (2010: 100) do not distinguish between (code switching and code-mixing) the two concepts. Authors like Amuda (1989), Atoye (1994), Belly (1976) and several others have, on the other hand, attempted to define Code-Switching and Code mixing.

For Baker and Jones (1988), "Code Switching describes any switch among languages in the course of a conversation, whether at the level of words, sentences or blocks of speech, such as what often occurs among bilinguals who speak the same language, whereas codemixing describes the mixing of two languages at the word level (i.e. one word in the sentence is in a different language).

Bokamba (1989) defines both concepts as follows:

Code Switching is the mixing of words, phrases and sentences from two distinct grammatical (sub) system across sentence boundaries within the same speech event... Code-mixing is the embedding of various linguistic units such as affixes (bound morphemes), words (unbound morphemes), phrases and clauses from a co-operative activity where the participants, in order to infer what is intended, must reconcile what they hear with what they understand.

Fasold (1984) defines Code-mixing as "the use of at least two distinct languages together to the extent that interlocutors change from one language to the other in the course of a single utterance. Jendra, (1988: 94) sees code mixing as" a mixing or combination of different variations within the same clause "whereas Mabule (2015:341) paraphrasing Poplack (2000) sees it as "expressions in which a mixture of the grammar of one language and 
another language is used without altering the grammar of the first language used".

Types of code-mixing include 'conversational code-mixing' which involves the deliberate mixing of two languages without an associated topic change" Wardhaugh (1992:107-108)

On the other hand, the phenomenon of code-switching in itself is of interest to sociolinguists, psycholinguists, general linguists, identity researchers and students of language who have carried out research on it. Consequently, specialists who have studied it from different points of view, "all of which have put greater emphasis on either the descriptive or theoretical aspect of the phenomenon" have closely scrutinized it (Reta; 2002:51).

So, existing literature on the concept includes Gal, (1982), Li Wei (1998), Sebba and Tony (1998), Oladunjoye (1991), Thelander (1994), and Akanle (1994); Olcay (2005:3), Paramaswan Muthusamy (2009:4), Cromdal (2001) among others.

"Process of shifting from one linguistic code (a language or dialect) to another, depending on the social context or conversational setting (Carlos D. Morrison, 2004), code switching is defined by Gumpers (1971: 1-34) as “... the juxtaposition within the same speech exchange of passages of speech belonging to two different grammatical systems . ...".

Hymes (1971), Grosjean (1982), Auer (1984/98), Scotton (1993) Muyeken (1995), Lambert (1997) MyersScotton (1998:p47), Kathryn Woolard (2004) and Bamisaye (2007) perceive it as the alternation of two or more languages. That is to say, it is the use of two or more linguistic varieties in the same conversation or interaction. Grosjean continued on to state: "The switch can happen within words, clauses, or sentences. However, there is only a switch in the language, not an integration of the word, clause or sentence into the language".

Moreover, for Romaine (1994:60), "switching" is a communicative option available to a bilingual member of a speech community. It occurs when conversants use both languages together to the extent that they change from one language to the other in the course of their discussion at different times. Jowitt (2000: 20), on the other hand asserts that switching may be conscious or apparently unconscious because it typically produces a hybridization of discourse.

As for its function, scholars like $\mathrm{Li}$ Wei (1998:156-176); Sebba and Tony (1998, 262: 286), Cromdal (2001:421-451) view Code Switching as a means of structuring talk in interactions. Kamisah Shameen (2009:3) studied Code Switching as a communication device in conversation. They stated that bilinguals use CS strategies to organize, enhance and enrich their speech in order to achieve their communication objectives.

In fact, according to Adendorff (1996:389) and Myers-scotton (1995) in Kamisha (2009:3), CS no more serves the objectives of compensation of linguistic deficiency but has become a functionally motivated behaviour. Barbara and Almeida (undated: 3) viewed CS as a phenomenon deriving from language contact (...) realized by bilinguals of "differing degree of proficiency living in various types of language contact settings" (Wardhaugh 1986:108).

With regards the types of Code switching, we can state with Romaine (ibid) that they are several types of codeswitching just as there are speakers that code-switch. Poplack (2000), Abdullahi Idiagbon (2007: 39), Hugues et al; 2006, Gompers (...) also recognize one or the other type. They are, among others: "intra-sentential" and "inter-sentential" switches, "metaphorical/rhetorical" and "transactional"/situational switches, "conversational" switching.

Most of the abovementioned types of mixing/switching are found to be in use in the national Assembly of Niger.

\section{INTRA SENTENTIAL CODE-SWITCHING (CODE MIXING)}

Often referred to as code mixing, intra-sentential switching, according to Gumperz (1971), Romaine (1994: 57) and Poplack (2000) refers to a situation where a switch from one language to another occurs within the boundaries of a clause or a sentence. This kind of switching, where speakers are seen to switch or mix languages from French to Hausa/Zarma and vice-versa is found in the Niger Chamber of Assembly during debates:

«Il est là-bas en réunion de la BAD, mutane sun taru, ministirori na duka kasashen : na Afirika, na Asie da kasashen larabawa; Déjà daga nan Niger wani ya yi telephoner cikin Assemblée Générale din; har an ba da labari. An ce, cewa ma aka yi dukan mu, duka députés suka yi déposer din motion de censure.»

\section{Meaning:}

He was attending the meeting of the African Bank of Development together with his peers' ministers from Africa, Asia, when call has been given to disclose the news to the 
general assembly. It has been reported that all of us, members of the NA has introduced a defeat motion. (...)

In this example, intra-sentential switching is used in an emphatic manner to show how fast and purposely the information has been given to the detriment of somebody.

«ministirori na Afirika suka zabi ministir din Niger ya yi representer din su. La raison (pause) mi ya sa suka zabi Niger? Par ce que, excusezmoi, a cikin pays na UEMOA Niger ce ta yi mobiliser din plus de mille/six milliards. Har ta fi Cote-d'Ivoire wadda ta fi mu économie. »

\section{Meaning}

African ministers have elected Niger Minister to represent them; why is it so? The reason (pause), why have they chosen Niger? This is, because among all members of ECOWAS only Niger happened to collect more than six billions in only 12 months that is to say one year out distancing Ivory Coast which outweigh Niger when it comes to economy.

In this example, the speaker switches code in an attempt to convince his colleagues. The switching occurs due to lack of equivalence (Baker, 1996:87-89), that some concepts are easier to express in one of the languages (Kareen, 2003:60) and sounds unconscious.

Moreover, code switching in this example, offers another language to use when words in the primary language are insufficient due to the speaker or listener's limited proficiency (Hugues et al, 2006:7); in these examples speakers seem to be deficient of the right Hausa terms to use for 'réunion', 'déjà', 'déposer', 'motion de censure' on the one hand and, 'représenter', 'mobiliser', 'milliards' and 'économie' on the other hand.

What the researcher finds out is that the speaker uses the two languages in an incipient manner that he proves to be an 'incipient bilingual' (Baker, 1997; Jowit, 2000).

\section{INTER-SENTENTIAL SWITCHING}

According to Hugues et al (2006) inter-sentential code switching "is inserting an entire phrase from the secondary language into a conversation using the other language" whereas according to scholars such as Gumperz (1971), Poplack (2000) and Romaine (1994: 57), intersentential switching refers to an instance where the switching occurs at a clause boundary. Note that this type is seen to be used mostly by bilinguals with a very good command of languages. The following examples of intersentential switching are found to be used during debates:

«Quant à la levée de l'immunité parlementaire des députés, c'était bien eux qui avaient interpellé le Ministre de la Justice pour l'obliger à suivre la procédure. $\mathrm{Mr}$ le Président, da kambe si fey nongu fo koyyan kulu han fo kulu a ga kande hari fo. (. . . ) La sanction divine, $\mathrm{Mr}$ le Président, Irikoy hinne no ga a bey. ( . . . ) Sanin gaibu sai lillahi. Je vous remercie. »

Meaning

"As for the stripping they were the ones who called on the Minister of Justice compelling him to follow the procedure (...).Divine sanction, Mr. President, only God knows.(...) No one knows. Thank you"

In this example, the speaker switches consciously (makes use of two other languages Zarma and Hausa) to recall a fact and emphasize the result of this fact.

«Ne vous en faites pas, c'est pas ce qu'on a compris; vous avez la parole vous faites ce que vous voulez. Nizeer laabiize kullu assalamu alaikum. Hunkuna wo manci zarma ciine kuuku fo no ay ga te aran se.(...). Hunkuna iri Niizer laabu bu. Ay ga kay aran se nongo ay ga sintin da faransi ciine. Mr le Président merci. L'article 10 de la Constitution de notre pays dit que les Nigériens naissent et demeurent libres et égaux en droit. Je n'en ai pas la preuve. (...).»

Meaning

Don't mind. You have the 
floor, say whatever you want. People of Niger, Peace be upon you. Today I am not going to be too long in my using Zarma (language) to address you but,(...). All I can say right now is our country, Niger is died. I will keep it there, to address you in French. Mr. President, thank you. Article 10 of our Constitution stipulates "All Nigeriens are born and live free, they are equal in law». I am doubting (...)"

The code switching used in this example serves to express one's worrying. It is consciously done as announced by the speaker that now he is going to start speaking in French!

«Merci Mr le Président. Mr le Président, i ne iri ma i yaafa. (...) Mr le Président iri yaafa amma iri si diryan. (...) $\mathrm{Mr}$ le Président, parlant de l'éducation et pour répondre à un député de la place à la question qui a dit ba mu son dogon ilimi, Mr le Président, cette question n'aura sans doute sa réponse que lorsque nous allons voter bientôt la mise en accusation de sa Majesté $\mathrm{Mr}$ le Premier Ministre. ... »

Meaning

Thank you Mr. President. Mr. President, they beg our pardon, we admit. $\mathrm{Mr}$. President, we forgive but we do not forget. (...). $\mathrm{Mr}$. President, with concerns education, to answer an MP who states "we don't want higher education" everything will be clear to him the time we will bring an accusation against its Majesty the Prime Minister.

What the researcher observed is that speakers above can be said to be co-ordinate bilinguals (Baker, 1997: Jowit; 2000) that means they are the type of bilinguals that use or speak two languages with almost equal ability.

\section{TRANSACTIONAL SWITCHING / SITUATIONAL SWITCHING}

Transactional switching, also called situational (Wardhaugh 1986:102) and Romaine (1994:61), occurs when conversants change language/variety of language without changing the topic. This type of switching is referred to as metaphorical or rhetoric code switching (Hugues) "often used in speech and rhetoric, on purpose in order to either attract attention or persuade an Audience."

This type of switching is also found in use by the National Assembly Members.

" $\mathrm{Na}$ gode shugaban majalisa (...) Hausawa sukan ce: makaho ga ido, ya ce': a'a, ba na so, wari yake'. Kassh!! Rakummin daji da ya ga rakummin gida ya ce :'Allah wadan naka ya lalace!(... ). Mr le President, au risque de nous répéter ce que je dirai tout simplement ce que le ridicule ne tue pas.(...) Ils sont en train de faire leur mea culpa. Donc ils implorent le pardon nonobstant tout ce qu'ils ont fait de mal. Comme nous sommes cléments et indulgents accordons le leur. Mu ba su don Allah. Merci. Merci Monsieur le Président je m'arrête ici. »

\section{Meaning}

«Thanks Mr President (...). As the Hausa say: blind man was offered an eye. $\mathrm{He}$ declined, saying "It smells awfully". Else, let sleeping dog lie. Mr. the President, at the risk of sounding repetitive I will simply state that people do not fear ridicule. Some forget that power belongs to the Almighty. But they own up. So they beg our pardon. As we are merciful and lenient lets grant them our pardon. For God's sake. Thanks. Thanks, Mr. President. I will keep it here. 
In this context, the speaker switches code to persuade his colleagues without sounding repetitive.

Merci Mr le Président. Je crois que le Premier Ministre a répondu valablement à toutes les préoccupations posées mais zarmey no ga ne «Iri ndunyyo wo ra, hini wo irkoy kamba ra no a go. Irkoy no ga no boro kan a ga ba se a ma a ta lokaci kan a ga ba.(...) Amma zarmey ga ne alaasirey a si wa bibandi.(...). Eh Mr le Président, sinon toutes les institutions démocratiques fortes, crédibles et durables sont mises en place; la ligne verte poursuit son travail, le respect de la Constitution est en vigueur, la garantie du Droit à l'égalité et du droit à la justice est sans faille; l'indépendance du magistrat est assurée. On se demande alors, quels sont les avis et les arrêts de la Cour Constitutionnelle qui n'ont pas été respectés?

\section{Meaning}

Thank you Mr. President. I think the PM has satisfactorily answered. As the Zarma say power belongs to God. He is the one who empowers whoever he wants whenever he wants (...). But, to blackmail is a normal doing of an idle-mind (...) Mr. President, strong, credible and long lasting institutions are insured, respect of the Constitution is in effect, the right to justice is flawless, magistrates are independencyminded, else, there is room to wonder those adjucations of the Constitutional Court that are no respected?

The speaker speaks largely in his native language and later on in French but, on the same topic to answer to another member's statement, to emphasize a particular point of view (Baker, 1996:87-89) during business debates.

\section{CONVERSATIONAL CODE SWITCHING}

Gumperz refers to conversational code switching as "when a speaker uses a second language either to reiterate his message or to reply to someone else's statement (Discourse Strategy, 1982). Janet Holmes (2000) describes conversational code-switching as" often used in speech and rhetoric, on purpose in order to either attract attention or persuade an Audience" that means "code switching will draw the participants' attention and will enhance their motivation to carefully scrutinize the message presented." Following is an instance where this type of switching is used during debates:

«Nous allons passer au vote de la motion de censure. Le vote sera organisé en scrutin public à bulletin secret. C'est un exercice auquel nous nous étions livrés lundi. . . . Je rappelle à toute fin utile que dans le cas de scrutin public, il est distribué à chaque député trois sortes de bulletin: blanc, s'il est pour l'adoption, s'il est pour l'adoption de la motion de censure; orange, s'il est contre l'adoption donc s'il est pour le rejet de la motion de censure; vert, s'il désire malgré tout s'abstenir. To, borey kan ga ma zarma sanni, ay ne bi fo attinin hane, iri voter ka immunité tunandi; hunkuna, fondo follonka no iri ga gana ka voter motion de censuro bon. Tira hinza no i ga fey warse: i kaara, i ma gomnati zumandi; borey kan ga ba i ma gomnati zumandi; i cira,gooro haro, borey kan ga ba gomnati a ma ye koy ka nga goyo te, goyo kan se wor nkulu salan; i bogo, ay ba si. I go no a si no kulu ay ba si. Yadinga, iri faham da care. Donc il faut expliquer ça en Hausa toi. Voilà, je te donne les trois cartes. »

Meaning:

Now let us take the vote. A vote by secret ballot. Remark 
that we already have done this kind of assignment. In this case, each MP will be given three different ballots: blank that means promotion of defeat; orange meaning against, and green that means abstention. Now, to those who understand Zarma language, I was saying that last Monday we voted the stripping that we have to go through the same process right now to vote the motion. You are going to be given out three types of ballot paper: white color, government should step-down that means those who want the government be dismissed (....); red color (...) those who want the government continue on carrying their duty; green: that means I don't care: whether they step-down or carry on, it doesn't matter. Hope we understand each other. So (you) translate it in Hausa; here are the ballots. They are three of them".

In this example, the speaker speaks largely in French, and then switches code to repeat the same thing in another language in order to reiterate his message, attract attention, clarify and emphasize the contents of the message.

Therefore, it proves Gumperz and Holmes's assertion right that conversational code switching serves to not only reiterate one's message but also enhance addressees' motivation to carefully scrutinize the message presented.

On the other hand, switching in this case, serves to express ethnic solidarity; it is a tool for creating linguistic solidarity (Malik, 1994), too.

Empirically speaking, it could be stated that conversational', 'transactional'; and 'inter-sentential' switching prove the speaker's degree or level of proficiency and their being 'co-ordinate bilinguals' which means speakers who speak two languages with equal ability.(Baker, 1997:15; Jowit, 2000; Yaro, 2002:10).

\section{FINDINGS}

Though the choice of code in conversation is often imposed by the situation or context of the ongoing conversations that is "Bilinguals are often forced to select a code" (Wardbaugh, 1986:100) in particular situation, majority of the members of the Assembly are found to be reluctant if not despising to switching codes during the course of debates business.

Nevertheless, there are a few, very few of them who make use of switching, consciously. Our data show different types of code switching occurring during the course of debates business at the National Assembly and confirm Baker's (1998) submission that «Code switching does not reflect linguistic incompetence, but rather linguistic skill" (p.59) and that of Poplack (2000) for whom "it is clear that code switching is a verbal skill requiring a large degree of competence in more than one language, rather than a defect arising from insufficient knowledge of one or the other language."

In fact, members of the Assembly speak largely and fluently (through inter sentential, transactional, conversational switching) in their native language or French and later on in French or native language with a good command of both languages.

Also that of Adendorff (1996:389) and Myers-scotton (1995) in Kamisha (2009:3), that code switching no more serves the objectives of compensation of linguistic deficiency but has become a functionally motivated behavior.

Moreover Code Switching is found to be "a valuable linguistic strategy" which does not happen at random" (Baker and Prys, p59), used considerably on purpose, by certain members of the Assembly for various reasons as follows: to show

$O$ concerns towards the masses and the less educated in western education (only $22 \%$ of the total population of Niger are literate in western education);

O concerns about their colleagues $(25 \%$ of the Assembly members are illiterate in western education).

allow the notable absentees- the population- follow the debates business, grasp something especially with regards "questions d'actualité", voting the budget and controlling government actions (.....)

O express communicative friendship (Baker, 1996), solidarity (Gumperz, Wardaugh (1992) Crystal (1987); Zentella, 1985)) with his /her listeners, to reduce social or cultural distance" Wardbaugh (1992: 106);

find the appropriate words or expressions to express meaning or concept that has no equivalent, reinforce request; Colin Baker (1997: 87), Almeida and Barbara(u d);

to reiterate one's message said in one code into another (without sounding repetitive) Gumperz (1983), to clarify and emphasize the content of a message/a particular point of view during the debates business; 
attract attention and persuade audience (Holmes, 2000).

On the other hand, as mentioned at the very beginning of this unit our data show a majority despising this linguistic strategy, inevitable and useful tool use by bilinguals to facilitate communication. Hence they illperceive those who code switch treating them as 'incompetent', feable with no command of the official language and disgracing them (reported verbatim pro verbo).

What we also found are MPs who do not know the Constitution and Law (cf Loi $\mathrm{n}^{\circ}$ 2001- $037 \mathrm{du} 31$ décembre 2001) as they even go far to suggest that selections are quite obviously necessary to be operated with regard a to-be member of National Assembly, that in no occasion/situation, a member should make use of his/ her native language during debates.

\section{ATTITUDE VIS À VIS CODE SWITCHING}

This unit attempts to discuss the possible reasons why Members of the Chamber of Niger Assembly unfortunately the majority- despise code switching and illperceive those who do it.

In spite of the assumption that: "In general, the social domain (e.g. family, work place, school, etc.), being an area of activity which is tied to a certain code, plays a major role in motivating and constraining code-switching, thus effecting the choice of codes being used for which topic while talking to which interlocutor", what the researcher sorts out is that the majority of the members is reluctant if not definitely despising to switch codes during their debates business while the sessions are open. Only a few do it proving Weinreich (1953:73) right when he claims: "the ideal bilingual is someone who is able to switch between languages when required to do so (...)."

Unfortunately, the members who code switch are viewed by their mates as mostly incompetent in either language. Why is it so? At this juncture it is important to remark that this attitude of theirs can be retraced back to the Constitution and to history in this sense:

1.The Constitution of Niger Republic does not stipulate clearly the business of the Chamber of Assembly shall be conducted in French in addition to one or more other spoken languages of the country as, does the Constitution of Nigeria, for instance.

2. 'The people in Niger Republic were colonised by the French while in Nigeria they were colonised by the English. And it stands for reason that their differing colonial policies made different effects and influence on the people. The policy of the colonial rule was not the same in both cases; it was different in respect of mode of administration. British colonial policy is based on indirect rule. In consequence, the people in Nigeria were left with their traditional values and beliefs pretty much as they were; as a result they use their languages freely for whatever matter. In Niger, the French ruled directly; the colonisation was an 'assimilatory one. The people in Niger must use French for whatever purpose.

In fact, French and English became the official and socially prestigious languages in the country they occupied.

Therefore, in Niger, to sound elitist it is a must for you to stick to French. Else you are seen to be incompetent. This is the case with the members of the Chamber of the Assembly as to our data. But what they fail to know is that "People are usually required to select a particular set of codes whenever they choose to speak. They also decide to switch from one code to another or mix codes even within sometimes every utterance $(\ldots)$ "; that "Bilinguals are often forced to select a code in particular situation,"(Wardbaugh, 2000:100; 1986:100) that "sociolinguistically, the practice of Code-Switching is motivated and constrained based on the situational and /or metaphorical situation, such as social context, affiliation, occupation, or personal affection. (... ). This is illustrated by the approximatively $78 \%$ of the population illiterate (the audience) and $25 \%$ of the members of the National Assembly (participants) non- educated in western education that constitute one of the inducing factor which plays a significant role.

In view of all these, Code Switching should be "a conversational strategy used to establish, cross or destroy group boundaries; to create, evoke or change interpersonal relations with their rights and obligations (Gal, 1988:247).

\section{CONCLUSION}

Owing to the constitutional 'vide', majority of members are found to despise using the national languages. They perceive the phenomena of switching and or mixing code as negative and those who practice it as incompetent in either language.

Hence, as the immediate language spoken by the majority is definitely ignored in the carrying debates by the members of the chamber, the masses and the less educated in western education in both rural and urban centers do not develop interest in listening to the sponsored program. Let alone voice their opinions over the issues being discussed.

This study is a step toward filling the 'vide' with regards the use of national languages by members of the chamber during the business debates.

\section{RECOMMANDATION}

This paper recommends :

^ The sensitizing those members - literate - of the 
Assembly to read "la loi no 2001-03 du 31 décembre 2001 fixant les modalities de promotion et de développement des langues nationales" in its Chapitre II article 3, 2, 4,8 et 6.

A The government to review the constitution in order to clearly recommend the usage of national languages in carrying out debates because, if performed by almost all the members of the National Assembly, the process of Code Switching would play a greater role in national development This would, because the population being represented nationwide at the NA would follow and listen to the live programme of the debate business that is being carried out over the broadcast media from the National Assembly.

In view of this, the population would equally use the media to prove to the NA- that it follows its deliberations by supporting or opposing what the assembly discusses or resolves in the chamber.

\section{REFERENCES}

[1] Abdullahi-Idiagbon, M.S. 2007. «Code-mixing with English and the future of the Nigerian Languages in Journal of the Nigerian English Studies Association, Vol. 3: 1Ikot Ekpene Nigeria: NESA \& DEV consort Publication

[2] Akanle, F.M. 1994. Code-switching and Code-mixing in social club meetings: A Case Study of Inland Club, Ado-Ekiti. Unpublished BA Long Essay, Department of English, Ondo State University, Ado-Ekiti.

[3] Akere, F.1977. A Sociolinguistic Study of a Yoruba Speech Community in Nigeria: Variation and Change in the Ijebu Dialect of Ikorodu, Ph.D. Thesis, University of Edinburgh.

[4] Anmda, A.1989. Attitudes to Code-switching: The case of Yoruba and English. Odu, New Series, No. 35.

[5] Ansre, G. 1971. The influence of English on West African Languages. In: J. Spencer

[6] (ed), The English Language in West Africa. Ibadan: Ibadan University press.

[7] Atoye, R.O. 1994. Code-mixing, Code-switching, Borrowing and Linguistic Competence: Some Conceptual Fallacies. In: B. Adediran (ed.), Cultural Studies in Ife. IIe-Ife: The Institute of Cultural Studies.

[8] Baker, C.and Jones,S.P. 1998. Encyclopedia of bilingualism and bilingual education. Clevedon, U.K: Multilingual Matters.

[9] Bamgbose, A. 1971. The English Language in Nigeria. In: J. Spencer (ed.), The English Language in West Africa. Ibadan: Ibadan University Press.

[10] Belly, R.T. 1976. Sociolinguistics: Goals, Approaches And Problems. London: B.T. Batsford Ltd.

[11] Bokamba, E. 1989. Are there Syntactic Constraints on Code-mixing World Englishes 8(3).
[12] Cheng, L. \& Butler, K. 1989. Code-swiching: A Natural Phenomenon vs. Language "Deficiency". World English 8(3)

[13] Constitution de la République du Niger, 2010

[14] Gal,S. 1988. The political economy of code choice. In M. Heller(Ed), Codeswitching. Berlin: Mouton de Gruyter.

[15] Gumperz, J.J. 1982. Discourse Strategies. Cambridge. University Press.

[16] Gumperz, 1971. Language in Social Groups Standford: Standford University Press.

[17] Gumperz, J. J. 1977. The Sociolinguistic Significance of Conversational Code- switching. RELC Journal, 8 (2): 1 $-34$

[18] Hornby, A.S. 2006. Oxford Advanced Learners Dictionary $\left(7^{\text {th }}\right.$ ed) Oxford University Press.

[19] Hudson, R. A. 1980. Sociolinguistics, Cambridge: Cambridge University Press.

[20] Hymes, D. 1962. The Ethnography in Speaking. In: T. Gladwin (ed.), Anthropology And Man Behaviour. Washington.

[21] 1974. Foundations In Sociolinguistics: An Ethnographic Approach. London:

[22] Jimoh, A.A. 1990. Law Practice and Procedure of Legislature. Lagos: Learned Publishments Limited.

[23] Jowitt. D. 2000. Nigerian English Usage: An Introduction. Lagos: Longman Nigeria Plc.

[24] Lambert, W.E. 1977. Effects of Bilingualism on the Individual in Hornby, p. (ed) Bilingualism: Psychological, Social and Educational Implications. New York: Academic Press.

[25] Kachru, Y. 1989. Code-mixing, Style Repertoire and Language Variation: English in Hind Poetic Creativity. World Englishes 8(3)

[26] Kamwangamalu, N. 1989. Code-mixing and Modernisation. World Englishes 8(3)

[27] Khalil El-Saghir. 2010. Code-Switching in Sociolinguistic Studies: Review and Analysis. Wayne State University.

[28] Mabule, D.R. 2015. What is this Is it Code switching, Code Mixing or Language Aternating Journal of Educational and Social Researcn. Vol 5 No.1 january 2015. MCSER Publishing, Rome-Italy

[29] Myers-Scotton C. 1993. Social motivations for codeswitching. Evidence from Africa. Ox Ford: Clarendon Press

[30] Myers-Scotton C. 1998. A theoretical instruction to the markedness model. In C Myers

[31] Poplack S. 2000. The History of African American English. Oxford: Blackwell

[32] Romaine, S. 1994. Language in Society: An Introduction to Sociolinguistics. New York: Oxford University Press, Inc.

[33] Thelander, M. 1976. Code-switching or code- 
mixing? Linguistic. Vol. 183. Paris: Mouton Publishers.

[34] Wardhaugh, R. 1986. An Introduction to Sociolinguistics. Oxford: Basil Blackwell Limited.

[35] 2000. Introduction to sociolinguistics. Beijin Foreign Language Teaching and Research Press.

[36] Weinreich. U 1953. Language in Contact. The Hague. Mouton 